\title{
Effects of Calcium Fructoborate on Levels of C-Reactive Protein, Total Cholesterol, Low-Density Lipoprotein, Triglycerides, IL-1 $\beta$, IL-6, and MCP-1: a Double-blind, Placebo-controlled Clinical Study
}

\author{
Otilia-Constantina Rogoveanu • George Dan Mogoșanu • Cornelia Bejenaru • \\ Ludovic Everard Bejenaru • Octavian Croitoru • Johny Neamțu • Zbigniew Pietrzkowski • \\ Tania Reyes-Izquierdo • Andrei Biţă • Iulia Daria Scorei • Romulus Ion Scorei
}

Received: 9 September 2014 / Accepted: 2 October 2014 / Published online: 30 November 2014

(C) The Author(s) 2014. This article is published with open access at Springerlink.com

\begin{abstract}
Calcium fructoborate (CFB) has been reported as supporting healthy inflammatory response. In this study, we assess the effects of CFB on blood parameters and proinflammatory cytokines in healthy subjects. This was a randomized, double-blinded, placebo-controlled trial. Participants received placebo or CFB at a dose of $112 \mathrm{mg} /$ day (CFB-1) or $56 \mathrm{mg} /$ day (CFB-2) for 30 days. Glucose, total cholesterol (TC), lowdensity lipoprotein (LDL), high-density lipoprotein (HDL),
\end{abstract}

\section{O.-C. Rogoveanu}

Department of Physical Medicine and Rehabilitation, University of Medicine and Pharmacy of Craiova, Craiova, Romania

\section{G. D. Mogoşanu • L. E. Bejenaru}

Department of Pharmacognosy and Phytotherapy, University of

Medicine and Pharmacy of Craiova, Craiova, Romania

C. Bejenaru

Department of Vegetal and Animal Biology, University of Medicine and Pharmacy of Craiova, Craiova, Romania

O. Croitoru

Department of Drug Control, University of Medicine and Pharmacy of Craiova, Craiova, Romania

J. Neamțu

Department of Physics, University of Medicine and Pharmacy of

Craiova, Craiova, Romania

Z. Pietrzkowski · T. Reyes-Izquierdo $(\square)$

Applied BioClinical Laboratory, Futureceuticals, Inc.,

16259 Laguna Canyon Rd, Irvine, CA 92618, USA

e-mail: tania@abclinicaldiscovery.com

A. Biță $\cdot$ I. D. Scorei • R. I. Scorei

BioBoron Research Institute, Craiova, Romania triglycerides (TG), C-reactive protein (CRP), homocysteine, interleukin 1 beta (IL-1 $\beta$ ), IL-6, and monocyte chemoattractant protein-1 (MCP-1) were determined before and after supplementation. CFB-1 showed a reduction in blood levels of CRP by $31.3 \%$ compared to baseline. CFB1 and CFB-2 reduced LDL levels by 9.8 and $9.4 \%$, respectively. CFB-1 decreased blood homocysteine by $5.5 \%$ compared with baseline, whereas CFB-2 did not have a significant effect. Blood levels of TG were reduced by 9.1 and $8.8 \%$ for CFB-1 and CFB-2, respectively. Use of both CFB-1 and CFB2 resulted in significantly reduced IL-6 levels, when compared within and between groups. IL-1 $\beta$ was reduced by $29.2 \%$ in the CFB-1 group. Finally, CFB-1 and CFB-2 reduced MCP-1 by 31 and $26 \%$, respectively. Our data indicate that 30-day supplementation with $112 \mathrm{mg}$ /day CFB (CFB-1) resulted in a significant reduction of LDL, TG, TC, IL-1 $\beta$, IL-6, MCP-1, and CRP. HDL levels were increased, when compared to baseline and placebo. These results suggest that CFB might provide beneficial support to healthy cardiovascular systems by positively affecting these blood markers (ClinicalTrials.gov, ISRCTN90543844; May 24, 2012 (http://www.controlled-trials.com/ISRCTN90543844)).

Keywords Clinical trial - Calcium fructoborate $\cdot$ MCP-1 · IL-6 · IL-1 $\beta \cdot$ Blood lipids · Triglycerides
Abbreviations
BMD Bone mineral density
BMI Body mass index
CFB Calcium fructoborate
CFB-1 112 mg of CFB per dose 


$\begin{array}{ll}\text { CFB-2 } & 56 \text { mg of CFB per dose } \\ \text { Chol. } & \text { Cholesterol } \\ \text { CRP } & \text { C-reactive protein } \\ \text { HDL } & \text { High-density lipoprotein } \\ \text { IL-1 } \beta & \text { Interleukin 1 beta } \\ \text { IL-6 } & \text { Interleukin 6 } \\ \text { LDL } & \text { Low-density lipoprotein } \\ \text { MCP-1 } & \text { Monocyte chemoattractant protein-1 } \\ \text { SD } & \text { Standard deviation } \\ \text { TC } & \text { Total cholesterol } \\ \text { TG } & \text { Triglycerides }\end{array}$

\section{Introduction}

Calcium fructoborate (CFB) is a nature-identical mimetic of a molecule naturally present in fruits and is commercially produced by a patented process that was first described by Miljkovic et al. (US Patent \#5,962,049) [1]. CFB has previously been reported as supporting healthy inflammatory response [2-4]. More recently published clinical research has shown that CFB may reduce knee discomfort and improve flexibility as measured by subjective evaluations such as the Western Ontario and McMaster Universities arthritis index (WOMAC) score and McGill index [5] and may modulate markers associated with inflammation $[4,6,7]$. In particular, $\mathrm{CFB}$ reduces circulating levels of C-reactive protein (CRP) [3, 4], an immune recognition protein that is a sensitive marker of inflammation $[4,8-10]$.

In general, current scientific evidence supports the hypothesis that the cardiovascular health is directly related and impacted by the body's inflammatory processes [11]. If this is the case, cardiovascular status could be monitored by measuring certain inflammatory biomarkers $[12,13]$. Concomitant evaluation of lipid levels, homocysteine, and CRP has been suggested to predict the risk of cardiovascular [14] and coronary heart [15-17] conditions. Other, more general, markers of inflammation such as interleukin (IL)-1 $\beta$ and IL-6 also provide useful information about cardiovascular risk [18]. Likewise, IL-1 $\beta$ is increasingly becoming recognized as a proatherogenic factor and biomarker of cardiovascular inflammation [19]. The objective of this study was to investigate whether CFB alters blood levels of lipids, homocysteine, CRP, IL-1 $\beta$, IL-6, and MCP-1 in generally healthy middle-aged subjects in order to evaluate the potential use of CFB as a dietary supplement to support cardiovascular health.

\section{Subjects and Methods}

\section{Ethics Approval}

This trial was approved by the Institutional Ethics Committee of the University of Medicine and Pharmacy of Craiova,
Romania, on May 3, 2012. In addition, the trial was performed in accordance with the guidelines put forth in the Declaration of Helsinki of 1975, which was last reviewed in 2008 [20]. An informed consent form was signed by every participant prior to beginning the trial.

\section{Inclusion and Exclusion Criteria}

Male and female participants were considered for inclusion, if they were between the ages of 40 and 60 years and had a body mass index (BMI) between 24 and $27 \mathrm{~kg} /$ $\mathrm{m}^{2}$, normal blood pressure or minor hypertension $(<140 /$ 80-90 mmHg), blood CRP $>3 \mathrm{mg} / \mathrm{L}$, LDL $>130 \mathrm{mg} / \mathrm{dL}$, elevated triglycerides $(>200 \mathrm{mg} / \mathrm{dL}), \mathrm{HDL}<40 \mathrm{mg} / \mathrm{dL}$, and fasting glucose $<100 \mathrm{mg} / \mathrm{dL}$. Participants were excluded if they had a diagnosis of or symptoms consistent with cardiovascular disorders (e.g., angina, shortness of breath), diabetes mellitus, renal failure, infectious or inflammatory disorders, active allergies, tobacco use, consumption of more than two alcoholic beverages per day, use of any supplements within 30 days prior to the initiation of the study, or use of statins, anti-hypertensive, anti-hyperlipidemia, anti-inflammatory, or anti-diabetic medications.

\section{Study Design and Intervention Administration}

Participants were randomly distributed into three groups with an identical number of females and males per group. Two participants from group A (initial $N=28$ ) and one participant from group C (initial $N=27$ ) were excluded because of noncompliance. The final number of participants analyzed in each group was 26. Baseline demographic data of the study groups is provided in Table 1. All included subjects were clinically healthy, and there were no significant demographic differences between groups. Subjects did not receive or take any additional nutritional supplements or other related products during the study. Participants were instructed to fast for at least $12 \mathrm{~h}$ prior to the beginning of the trial. Supplements were

Table 1 Baseline demographic characteristics of subjects that successfully completed the study

\begin{tabular}{llll}
\hline & $\begin{array}{l}\text { Placebo } \\
\text { (group B) }\end{array}$ & $\begin{array}{l}\text { CFB-2 } \\
\text { (group C) }\end{array}$ & $\begin{array}{l}\text { CFB-1 } \\
\text { (group A) }\end{array}$ \\
\hline $\begin{array}{c}\text { Number of participants } \\
\text { per group }(N)\end{array}$ & 26 & 26 & 26 \\
$\begin{array}{lll}\text { Men/women }(n) \\
\text { Age (mean } \pm \mathrm{SD} \text { ) [years] }\end{array}$ & $10: 16$ & $11: 15$ & $13: 13$ \\
Environment (rural/urban) & $0: 26$ & $56 \pm 6.8$ & $51 \pm 5.6$ \\
BMI (mean $\pm \mathrm{SD}$ ) $\left[\mathrm{kg} / \mathrm{m}^{2}\right]$ & $26.34 \pm 4.23$ & $25.32 \pm 1.69$ & $26.89 \pm 4.99$ \\
\hline
\end{tabular}

$B M I$ body mass index, $C F B$ calcium fructoborate, $S D$ standard deviation 
Table 2 Comparison of blood parameters between day 1 and day 30

\begin{tabular}{|c|c|c|c|c|c|c|}
\hline & Treatment & Number & Day 1 & Day 30 & $p$ value $\mathrm{n}$ & $e t^{a}$ \\
\hline & & & $197.6 \pm 33.8$ & $186.7 \pm 26.7$ & $<0.001$ & $* * *$ \\
\hline \multirow[t]{6}{*}{ Total cholesterol } & $\mathrm{A}$ & 26 & $189.9(150.3-267.7)$ & $185.2(147.1-254.9)$ & & \\
\hline & & & $194.5 \pm 23.2$ & $193 \pm 20.4$ & 0.178 & \\
\hline & $\mathrm{B}$ & 26 & $191.1(160.7-254.9)$ & $191.9(157-243.8)$ & & \\
\hline & & & $193.4 \pm 43.1$ & $180.1 \pm 38.1$ & $<0.001$ & $* * *$ \\
\hline & $\mathrm{C}$ & 26 & $192.8(77.4-317.1)$ & $180.9(73.9-269.2)$ & & \\
\hline & & & $46.1 \pm 11.1$ & $47.7 \pm 10.3$ & 0.243 & \\
\hline \multirow[t]{6}{*}{ HDL-Chol. } & $\mathrm{A}$ & 26 & $45.1(21.3-63.8)$ & $48.2(19.3-63.0)$ & & \\
\hline & & & $45.9 \pm 9.6$ & $46.0 \pm 9.3$ & 0.611 & \\
\hline & $\mathrm{B}$ & 26 & $43.2(34.2-65.2)$ & $45.2(30.9-65.0)$ & & \\
\hline & & & $43.9 \pm 8.2$ & $45.7 \pm 7.6$ & 0.003 & $* *$ \\
\hline & $\mathrm{C}$ & 26 & $42.8(33.1-61.2)$ & $45(33.9-61.7)$ & & \\
\hline & & & $145 \pm 23.2$ & $129.7 \pm 16.4$ & $<0.001$ & $* * *$ \\
\hline \multirow[t]{6}{*}{ LDL-Chol. } & A & 26 & $148.7(103.0-188.7)$ & $128.0(98.3-160.5)$ & & \\
\hline & & & $132.0 \pm 19.7$ & $129.6 \pm 18.4$ & 0.0912 & \\
\hline & $\mathrm{B}$ & 26 & $134.6(100.1-185.4)$ & $128.9(103.8-183.9)$ & & \\
\hline & & & $139.3 \pm 24.8$ & $125.8 \pm 24.1$ & $<0.001$ & $* * *$ \\
\hline & $\mathrm{C}$ & 26 & $138.7(96.9-202.0)$ & $122.8(74.8-169.3)$ & & \\
\hline & & & $163.2 \pm 39.4$ & $145.5 \pm 25.4$ & $<0.001$ & $* * *$ \\
\hline \multirow[t]{6}{*}{ Triglycerides } & A & 26 & $155.9(117.0-254.6)$ & $140.0(104.6-211.1)$ & & \\
\hline & & & $165.1 \pm 33.0$ & $161.5 \pm 26.0$ & 0.075 & \\
\hline & $\mathrm{B}$ & 26 & $163.9(120.0-246.6)$ & $161.3(121.4-214.3)$ & & \\
\hline & & & $181.4 \pm 33.1$ & $163.9 \pm 23.4$ & $<0.001$ & $* * *$ \\
\hline & $\mathrm{C}$ & 26 & $185.0(122.3-238.1)$ & $164.9(115.6-200.2)$ & & \\
\hline & & & $78.7 \pm 12.0$ & $76.3 \pm 11.9$ & 0.007 & $* *$ \\
\hline \multirow[t]{6}{*}{ Glucose } & $\mathrm{A}$ & 26 & $81.6(60.6-100.1)$ & $75.3(58.7-98.5)$ & & \\
\hline & & & $73.7 \pm 8.6$ & $73.1 \pm 7.8$ & 0.424 & \\
\hline & $\mathrm{B}$ & 26 & $71.0(61.2-99.3)$ & $73.1(63.2-99.1)$ & & \\
\hline & & & $75.0 \pm 11.3$ & $75.3 \pm 10.9$ & 0.859 & \\
\hline & $\mathrm{C}$ & 26 & $71.7(54.2-100.2)$ & $76.1(54.0-97.9)$ & & \\
\hline & & & $3.6 \pm 3.0$ & $2.4 \pm 2.0$ & $<0.001$ & $* * *$ \\
\hline \multirow[t]{6}{*}{ hs-CRP } & A & 26 & $2.8(0.6-12.4)$ & $1.6(0.5-8.2)$ & & \\
\hline & & & $3.5 \pm 2.9$ & $3.0 \pm 1.9$ & 0.086 & \\
\hline & $\mathrm{B}$ & 26 & $2.9(0.6-11.3)$ & $2.9(0.1-7.7)$ & & \\
\hline & & & $3.6 \pm 2.2$ & $2.7 \pm 1.4$ & 0.031 & $*$ \\
\hline & $\mathrm{C}$ & 26 & $3.6(0.2-7.6)$ & $2.5(0.4-5.7)$ & & \\
\hline & & & $16.8 \pm 10.4$ & $14.4 \pm 8.9$ & 0.004 & $* *$ \\
\hline \multirow[t]{6}{*}{ Homocysteine } & $\mathrm{A}$ & 26 & $14.5(2.5-41.2)$ & $12.6(2.3-37.4)$ & & \\
\hline & & & $19.6 \pm 12.7$ & $19.1 \pm 12.6$ & 0.374 & \\
\hline & $\mathrm{B}$ & 26 & $17.2(5.4-55.2)$ & $11.7(6.8-53.8)$ & & \\
\hline & & & $16.4 \pm 9.9$ & $15.0 \pm 9.1$ & 0.091 & \\
\hline & $\mathrm{C}$ & 26 & $13.4(5.2-38.2)$ & $11.3(4.7-35.6)$ & & \\
\hline & & & $3.2 \pm 2.6$ & $2.0 \pm 1.8$ & $<0.001$ & $* * *$ \\
\hline \multirow[t]{2}{*}{ IL-1 $\beta$} & A & 26 & $2.5(0.4-9.4)$ & $1.2(0.4-6.3)$ & & \\
\hline & & & $2.2 \pm 1.8$ & $2.1 \pm 1.8$ & $<0.001$ & $* * *$ \\
\hline
\end{tabular}


Table 2 (continued)

\begin{tabular}{|c|c|c|c|c|c|c|}
\hline & Treatment & Number & Day 1 & Day 30 & \multicolumn{2}{|c|}{$p$ value within-treatment ${ }^{\mathrm{a}}$} \\
\hline & $\mathrm{B}$ & 26 & $1.7(0.5-7.8)$ & $1.4(0.3-7.4)$ & & \\
\hline & & & $3.7 \pm 3.0$ & $2.8 \pm 2.4$ & $<0.001$ & $* * *$ \\
\hline & $\mathrm{C}$ & 26 & $3.1(0.5-12.4)$ & $2.3(0.3-11.7)$ & & \\
\hline & & & $8.2 \pm 9.3$ & $6.7 \pm 7.8$ & $<0.001$ & $* * *$ \\
\hline \multirow[t]{6}{*}{ IL-6 } & A & 26 & $6.4(0.4-44.2)$ & $5.4(0.4-35.7)$ & & \\
\hline & & & $8.8 \pm 8.4$ & $8.2 \pm 7.8$ & $<0.001$ & $* * *$ \\
\hline & $\mathrm{B}$ & 26 & $5.3(0.8-32.3)$ & $5.1(0.6-29.7)$ & & \\
\hline & & & $7.8 \pm 6.7$ & $6.7 \pm 7.8$ & $<0.001$ & $* * *$ \\
\hline & $\mathrm{C}$ & 26 & $6.3(0.3-20.9)$ & $5.3(0.2-20.7)$ & & \\
\hline & & & $281.7 \pm 53.5$ & $195.3 \pm 42.9$ & $<0.001$ & $* * *$ \\
\hline \multirow[t]{5}{*}{ MCP-1 } & A & 26 & $277.4(184.6-380.4)$ & $191.4(110.4-270.1)$ & & \\
\hline & & & $305.1 \pm 81.7$ & $256.0 \pm 63.8$ & $<0.001$ & $* * *$ \\
\hline & $\mathrm{B}$ & 26 & $273.4(215.5-507.4)$ & $243.5(134.6-383.7)$ & & \\
\hline & & & $291.8 \pm 68.7$ & $221.8 \pm 36.9$ & $<0.001$ & $* * *$ \\
\hline & C & 26 & $283.5(181.3-483.6)$ & $212.6(169.1-290.4)$ & & \\
\hline
\end{tabular}

Mean values $( \pm \mathrm{SD})$ and median values (range) for each parameter and time point are provided $(N=26$ within each study group). $p$ values were obtained by Wilcoxon signed-rank tests. Group A, CFB-1 (112 mg/day CFB); group B, placebo; group C, CFB-2 (56 mg/day CFB)

${ }^{\mathrm{a}} p$ values are from Wilcoxon signed-rank test

$* * * p<0.001 ; * * p<0.01 ; * p<0.05$

distributed to the participants after initial blood collection on the first day of the trial. All preparations were provided as identically colored capsules in identical bottles. The test formulation was CFB, a patented commercially available dietary supplement that has been tested in three previous clinical studies [4-6]. Group A (CFB-1) received $112 \mathrm{mg}$ /day of CFB given as a 56-mg dose twice daily, which is the equivalent to $3.0 \mathrm{mg}$ boron/day. Group C (CFB-2) received $56 \mathrm{mg} /$ day CFB as a 28-mg dose twice daily, the equivalent to $1.5 \mathrm{mg}$ boron/day. Even though the diet was not monitored, it has been reported that the foods commonly consumed by Romanians in urban and rural zones are within $2.0 \pm 0.7 \mathrm{mg} /$ day per person [8]. Group B, the placebo arm, received $80 \mathrm{mg} /$ day fructose given as a 40-mg dose twice daily; this dosage is equal to the amount of fructose present in $112 \mathrm{mg}$ CFB. To ensure compliance, extra capsules were added to each bottle, and periodic phone calls and reminders to the participants were made.

\section{Biochemical and Immunological Assessment}

For biochemical analyses, samples of fasting venous blood were drawn in the morning of the inclusion day and after 30 days. Blood was drawn from the antecubital vein into "dry" serum tubes (BD Vacutainer, Franklin Lakes, NJ, USA). Upon clotting, blood was centrifuged and serum was collected for analysis of blood chemistry parameters, such as
TC, HDL, LDL, TG, glucose, and CRP, using standard biochemical procedures.

\section{Statistical Analyses}

Descriptive statistics are reported as mean \pm standard deviation (SD) or median (minimum-maximum) in Table 2. $p$ values for each parameter based on comparison of the results at day 1 versus day 30 were calculated using Wilcoxon signed-rank test. Normalized data were calculated based on the percent change from baseline [(measurement at day 30/measurement at day 1$) \times 100]$. We tested the significance of differences in normalized data between groups using the Kruskal-Wallis one-way ANOVA on ranks test. All multiple pairwise comparisons were made using Tukey's honest significant difference (HSD) post hoc tests for each parameter. In addition, $p$ values from Kruskal-Wallis one-way ANOVA test for each parameter were calculated. Percentage change among the groups was analyzed using one-way ANOVA on ranks tests. Finally, $p$ values of Tukey's HSD tests for each comparison between groups were also calculated (Table 3 ).

\section{Safety Assessment}

Tolerance was evaluated at each visit by asking subjects about the appearance of any unexpected side effects. 
Table 3 Summary of changes from baseline between groups and pairwise multiple comparisons for each parameter

\begin{tabular}{|c|c|c|c|c|c|c|c|c|}
\hline \multirow{2}{*}{ Total cholesterol } & \multirow{2}{*}{$\begin{array}{l}\text { Group A } \\
95.1 \pm 5.8\end{array}$} & \multirow{2}{*}{$\begin{array}{l}\text { Group B } \\
99.5 \pm 5.7\end{array}$} & \multirow{2}{*}{$\begin{array}{l}\text { Group C } \\
93.4 \pm 5.1\end{array}$} & \multicolumn{2}{|c|}{$p$ value between-groups ${ }^{\mathrm{a}}$} & \multirow{2}{*}{$\begin{array}{l}\text { Post hoc comparison } \\
\text { B-A }\end{array}$} & \multicolumn{2}{|c|}{ Adjusted $p$ value $^{\mathrm{b}}$} \\
\hline & & & & $<0.001$ & $* * *$ & & 0.027 & $*$ \\
\hline & $95.4(84.6-106.9)$ & $99.2(82.0-15.3)$ & $95.2(82.6-101.8)$ & & & C-A & 0.667 & \\
\hline & & & & & & C-B & $<0.001$ & $* * *$ \\
\hline \multirow[t]{2}{*}{ HDL-Chol. } & $105.8 \pm 20.9$ & $100.5 \pm 8.6$ & $104.6 \pm 6.7$ & 0.207 & & & & \\
\hline & $103.9(62.1-171.8)$ & $101.0(76.5-18.7)$ & $104.7(89.0-118.5)$ & & & & & \\
\hline \multirow[t]{3}{*}{ LDL-Chol. } & $90.2 \pm 7.7$ & $98.6 \pm 7.1$ & $90.6 \pm 10.3$ & $<0.001$ & $* * *$ & B-A & $<0.001$ & $* * *$ \\
\hline & $91.4(75.3-101.0)$ & $99.2(76.4-111.3)$ & $96.4(70.0-102.7)$ & & & C-A & 0.816 & \\
\hline & & & & & & C-B & 0.01 & $* *$ \\
\hline \multirow[t]{3}{*}{ Triglycerides } & $90.9 \pm 10.4$ & $99.0 \pm 11.1$ & $91.2 \pm 7.1$ & $<0.001$ & $* * *$ & B-A & 0.007 & $* *$ \\
\hline & $91.5(72.4-113.3)$ & $98.8(73.0-129.3)$ & $93.4(78.7-99.7)$ & & & C-A & 0.965 & \\
\hline & & & & & & C-B & 0.003 & $* *$ \\
\hline \multirow[t]{3}{*}{ Glucose } & $97.1 \pm 6.7$ & $99.4 \pm 3.8$ & $100.5 \pm 4.0$ & 0.048 & * & B-A & 0.27 & \\
\hline & $98.3(81.6-111.0)$ & $98.5(90.4-105.4)$ & $99.5(94.4-111.0)$ & & & C-A & 0.046 & $*$ \\
\hline & & & & & & C-B & 0.813 & \\
\hline \multirow[t]{3}{*}{ hs-CRP } & $68.7 \pm 14.4$ & $89.5 \pm 36.3$ & $118.1 \pm 139.9$ & 0.045 & $*$ & B-A & 0.022 & $*$ \\
\hline & $70.6(41.3-92.3)$ & $86.4(16.7-209.1$ & $77.7(30.8-700.0)$ & & & C-A & 0.569 & \\
\hline & & & & & & C-B & 0.803 & \\
\hline \multirow[t]{2}{*}{ Homocysteine } & $94.5 \pm 54.1$ & $101.9 \pm 30.2$ & $97.7 \pm 32.3$ & 0.119 & & & & \\
\hline & $81.1(55.1-334.1)$ & $96.2(43.0-173.9)$ & $87.9(52.0-177.1)$ & & & & & \\
\hline \multirow[t]{3}{*}{ IL-1 $\beta$} & $70.8 \pm 32.3$ & $84.1 \pm 15.0$ & $78.0 \pm 15.3$ & 0.022 & $*$ & B-A & 0.035 & $*$ \\
\hline & $75.0(16.7-171.4)$ & $88.2(55.6)-104.7)$ & $82.3(35.7-100.0)$ & & & C-A & 0.242 & \\
\hline & & & & & & C-B & 0.305 & \\
\hline \multirow[t]{3}{*}{ IL-6 } & $80.8 \pm 12.5$ & $90.8 \pm 10.4$ & $79.6 \pm 16.3$ & 0.008 & $* *$ & B-A & 0.025 & $*$ \\
\hline & $79.5(42.9-100.0)$ & $93.6(66.7-109.5)$ & $82.3(35.7-100.0)$ & & & C-A & 1 & \\
\hline & & & & & & C-B & 0.032 & $*$ \\
\hline \multirow[t]{3}{*}{ MCP-1 } & $70.1 \pm 12.7$ & $87.2 \pm 20.2$ & $78.7 \pm 15.7$ & $<0.001$ & $* * *$ & B-A & 0.002 & $* *$ \\
\hline & 70.7 (43.7-99.6) & $96.3(28.2-107.9)$ & $81.6(46.7-107.1)$ & & & C-A & 0.078 & \\
\hline & & & & & & C-B & 0.033 & $*$ \\
\hline
\end{tabular}

Changes from baseline ( $\%$ change) for each parameter are summarized as mean $\pm \mathrm{SD}$ or median (range). Group A, CFB-1 (112 mg/day CFB); group B, placebo; group C, CFB-2 (56 mg/day CFB)

${ }^{\text {a }} p$ values are from Kruskal-Wallis one-way ANOVA test

${ }^{\mathrm{b}}$ Adjusted $p$ values are from Tukey's HSD test

${ }^{* * *} p<0.001 ;{ }^{* *} p<0.01 ;{ }^{*} p<0.05$

\section{Results}

\section{Participant Demographics}

The flow chart for subject recruitment and the various steps of this double-blinded, placebo-controlled study is presented in Fig. 1. The total number of enrolled subjects was 94. Of these, four individuals were found to have diabetes and were excluded from the trial, and 90 met the inclusion criteria. These subjects were randomized into three groups: placebo, $\mathrm{CFB}$ at a dose of $112 \mathrm{mg} / \mathrm{day}$ (CFB-1), and CFB at a dose of $56 \mathrm{mg} /$ day (CFB-2). Twelve subjects were later excluded because of lack of compliance; therefore, 78 subjects completed the entire protocol, and the final number of subjects analyzed in each group was 26. After these adjustments, the final study population included a higher number of females than males (56 and $44 \%$, respectively). 
Fig. 1 Flowchart for subject recruitment and study progression. $C F$ calcium fructoborate, ITT intention to treat, $P P$ patients, $t x$ study treatment

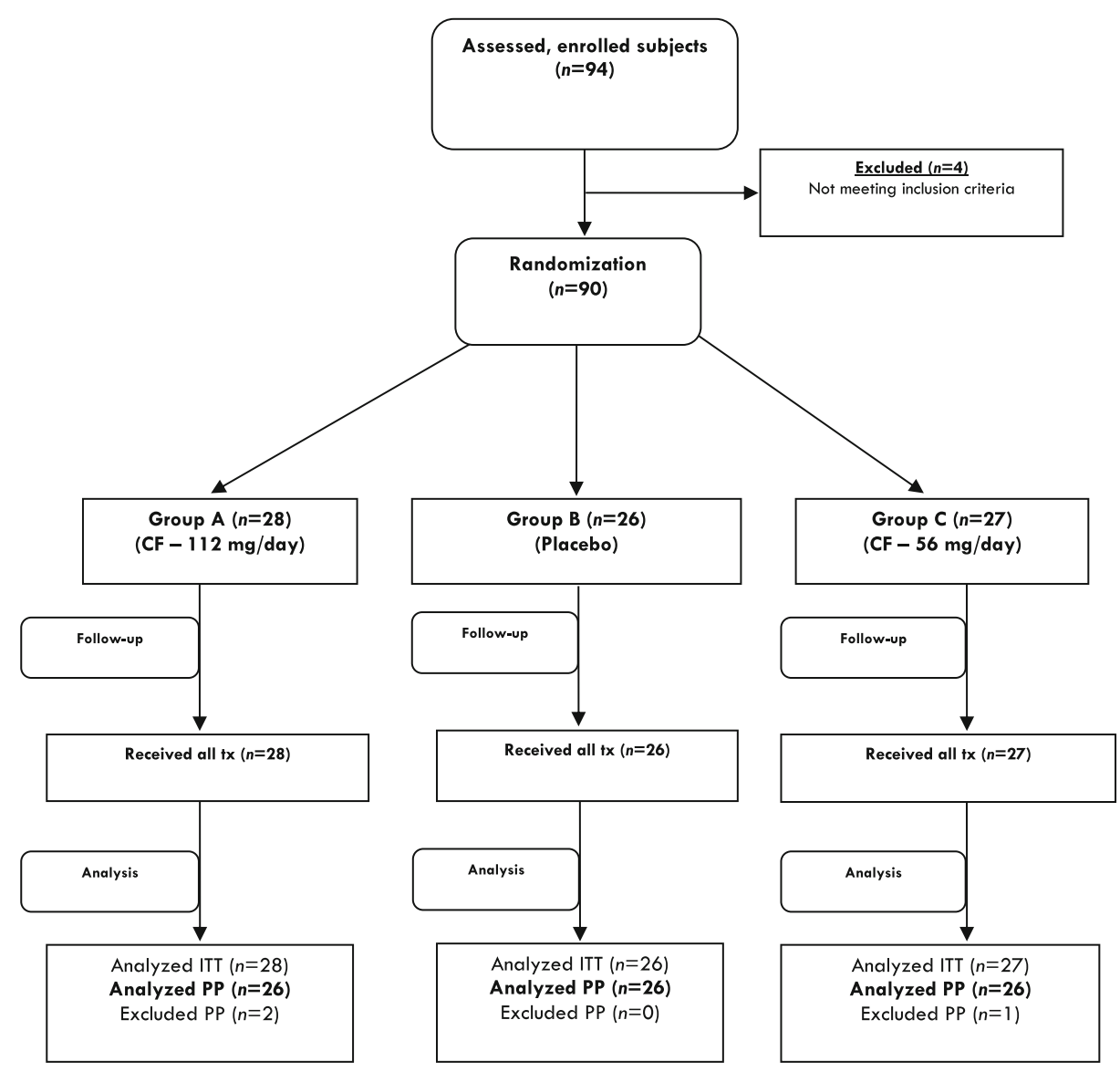

Analysis Within Study Groups (Day 1 Versus Day 30)

No adverse effects were reported for either of the supplementation doses. Table 2 presents statistical analyses of the lipid profile, fasting glucose, homocysteine, and CRP values for all groups of the study population. A significant decrease in the levels of TC, LDL, TG, and CRP was observed in groups A and $\mathrm{C}$ but not in group $\mathrm{B}$. The levels of glucose and homocysteine were significantly decreased in the CFB-1 supplementation group but were not significantly altered in the placebo or CFB-2 supplementation groups. Interestingly, HDL was significantly increased by CFB-2, but not by CFB-1 or placebo. The Pearson's correlation coefficients for group A (CFB-1) were 0.96 for TC $(p<0.001), 0.85$ for LDL $(p<0.001), 0.90$ for TG $(p<0.001), 0.94$ for CRP $(p<0.001)$, 0.82 for homocysteine $(p=0.004)$, and 0.91 for glucose $(p<0.007)$. For group C $(\mathrm{CFB}-2)$, the Pearson's correlation coefficients were 0.94 for TC $(p<0.001), 0.95$ for HDL $(p<0.003), 0.83$ for LDL $(p<0.001), 0.91$ for TG $(p<0.001)$, and 0.54 for CRP $(p<0.031)$.

Analysis Between Study Groups

Table 3 shows analysis based on change from baseline serum levels over 30 days. Significant differences were found between groups $\mathrm{A}$ (CFB-1) and $\mathrm{B}$ (placebo), and between groups $\mathrm{C}$ (CFB-2) and $\mathrm{B}$ (placebo) for TC, LDL, and TG, which showed significantly lower levels in both test groups (CFB at 112 or $56 \mathrm{mg}$ ) compared with the placebo group. HDL levels were significantly higher in the CFB-2 group compared with the placebo control. CRP levels were significantly lower in the CFB-1 group compared to placebo. Use of CFB-1 resulted in a significant decrease in IL- $1 \beta$ levels compared to placebo. Similarly, the CFB-2 group showed a slight decrease in IL-1 $\beta$, but this value was not significantly different from that in the placebo group. Study subjects using CFB1 and CFB-2 (groups A and C) experienced a statistically significant reduction in the level of IL- 6 and MCP-1 compared to the placebo group.

\section{Discussion}

Lipids and lipoproteins are well-known risk factors for development of heart conditions [14]. Elevated levels of TG, TC, and LDL, as well as low levels of HDL, are well-documented risk factors for atherogenesis [21]. In addition, CRP and homocysteine have emerged as important indicators of risk for cardiovascular conditions $[14,15]$. Although they are not 
currently routinely included in clinical cardiovascular risk assessments, various proinflammatory biomarkers have been strongly associated with the development of cardiovascular conditions. One of the most intriguing of these is MCP-1. MCP-1 is produced by various cell types within the arterial wall, and its expression can be induced by a number of substances including cytokines [22], minimally modified LDL [23], homocysteine [24], shear stress [25], among other factors [26]. Expression of MCP-1 by macrophages increases the progression of atherosclerosis [27, 28]. Conversely, it has been reported that MCP-1 knockout mice are markedly protected from macrophage recruitment and atherosclerotic lesions [29]. In humans, plasma levels of MCP-1 correlate with the severity of cardiovascular conditions [30, 31]. Several researchers have postulated that blocking or reducing the expression of MCP-1 might be beneficial in preventing the development of unhealthy heart conditions $[26,32]$.

IL-1 $\beta$ and IL- 6 are cytokines that provide clues to the presence of inflammatory processes. Systemic increases in these inflammatory molecules, together with tumor necrosis factor and CRP, occur during the atherosclerosis process [33, 34]. IL- $1 \beta$ modulates the atherogenic process by contributing to the arterial wall inflammation, leukocyte chemotaxis/adhesion, and the rupture of atherosclerotic plaques [35]. Therefore, blood levels of IL- 6 alone or in combination with other biomarkers are predictive of coronary pathologies $[18,36$, 37]. It therefore follows that a reduction in the blood levels of these inflammatory cytokines could be considered as an approach to support healthy cardiovascular systems and cardiovascular health in healthy subjects [38].

Our results suggest that use of CFB at a daily dose as low as $112 \mathrm{mg}$ for 30 days may significantly reduce levels of the proinflammatory and proatherogenic markers TC, LDL, triglycerides, CRP, and homocysteine while increasing the levels of HDL, which is considered a protective lipid. Furthermore, supplemental use of CFB at a dose of $112 \mathrm{mg}$ per day appears to have a statistically significant inhibitory effect on proinflammatory cytokines such as IL-1 $\beta$, IL-6, and MCP-1.

Limitation Further studies with larger groups of subjects are necessary to verify and confirm the effects of CFB on proinflammatory markers. Also, a study with a longer timeframe could establish the long-term benefits of CFB supplementation.

\section{Conclusions}

Under these experimental conditions, we observed a statistically significant reduction in the blood levels of TC, LDL, TG, CRP, homocysteine, IL-1 $\beta$, IL-6, and MCP-1 and an increase in the level of HDL. Consequently, CFB exerts beneficial effects on these subclinical blood markers within a healthy population. This study highlights the ability of CFB to maintain a healthy lipid profile (especially for LDL and TG) and to support the maintenance of healthy blood levels of proinflammatory markers in middle-aged healthy subjects.

Open Access This article is distributed under the terms of the Creative Commons Attribution License which permits any use, distribution, and reproduction in any medium, provided the original author(s) and the source are credited.

\section{References}

1. Miljkovic D, Scorei RI, Cimpoiașu VM, Scorei ID (2009) Calcium fructoborate: plant-based dietary boron for human nutrition. J Diet Suppl 6:211-226. doi:10.1080/19390210903070772

2. Scorei IR, Ciofrangeanu C, Ion R, Cimpean A, Galateanu B, Mitran $\mathrm{V}$, Iordachescu D (2010) In vitro effects of calcium fructoborate upon production of inflammatory mediators by LPS-stimulated RAW 264.7 macrophages. Biol Trace Elem Res 135:334-344. doi:10. 1007/s12011-009-8488-5

3. Scorei ID, Scorei IR (2013) Calcium fructoborate helps control inflammation associated with diminished bone health. Biol Trace Elem Res 155:315-321. doi:10.1007/s12011-013-9800-y

4. Scorei IR, Mitrut P, Petrisor I, Scorei ID (2011) A double-blind, placebo-controlled pilot study to evaluate the effect of calcium fructoborate on systemic inflammation and dyslipidemia markers for middle-aged people with primary osteoarthritis. Biol Trace Elem Res 144:253-263. doi:10.1007/s12011-011-9083-0

5. Reyes-Izquierdo T, Phelan MJ, Keller R, Argumedo R, Shu C, Pietrzkowski Z (2014) Short therm efficacy of a combination of glucosamine and chondroitin sulfate compared to a combination of glucosamine, chondroitin sulfate and calcium fructoborate (CFB) on improvement of knee discomfort conditions in healthy subjects. A comparative, double-blind, placebo controlled acute clinical study. JARCP (in press)

6. Reyes-Izquierdo T, Nemzer B, Gonzalez AE, Zhou Q, Argumedo R, Shu C, Pietrzkowski Z (2012) Short-term intake of calcium fructoborate improves WOMAC and McGill scores and beneficially modulates biomarkers associated with knee osteoarthritis: a pilot clinical double-blinded placebo-controlled study. Am J Biomed Sci 4:111-122. doi:10.5099/aj120200111

7. Scorei IR (2011) Calcium fructoborate: plant-based dietary boron as potential medicine for cancer therapy. Front Biosci (Schol Ed) 3:205215

8. Militaru C, Donoiu I, Craciun A, Scorei ID, Bulearca AM, Scorei RI (2013) Oral resveratrol and calcium fructoborate supplementation in subjects with stable angina pectoris: effects on lipid profiles, inflammation markers, and quality of life. Nutrition 29:178-183. doi:10. 1016/j.nut.2012.07.006

9. Danesh J, Wheeler JG, Hirschfield GM, Eda S, Eiriksdottir G, Rumley A, Lowe GD, Pepys MB, Gudnason V (2004) C-reactive protein and other circulating markers of inflammation in the prediction of coronary heart disease. N Engl J Med 350:1387-1397. doi:10. 1056/NEJMoa032804

10. Li JJ, Fang CH (2004) C-reactive protein is not only an inflammatory marker but also a direct cause of cardiovascular diseases. Med Hypotheses 62:499-506. doi:10.1016/j.mehy.2003.12.014

11. Ross R (1999) Atherosclerosis - an inflammatory disease. N Engl J Med 340:115-126. doi:10.1056/NEJM199901143400207

12. Packard RR, Libby P (2008) Inflammation in atherosclerosis: from vascular biology to biomarker discovery and risk prediction. Clin Chem 54:24-38. doi:10.1373/clinchem.2007.097360 
13. Armstrong EJ, Morrow DA, Sabatine MS (2006) Inflammatory biomarkers in acute coronary syndromes: part I: introduction and cytokines. Circulation 113:e72-e75. doi:10.1161/ CIRCULATIONAHA.105.595520

14. Yoldas T, Gonen M, Godekmerdan A, Ilhan F, Bayram E (2007) The serum high-sensitive $\mathrm{C}$ reactive protein and homocysteine levels to evaluate the prognosis of acute ischemic stroke. Mediat Inflamm 2007:15929. doi:10.1155/2007/15929

15. Bhupathiraju SN, Alekel DL, Stewart JW, Hanson LN, Shedd KM, Reddy MB, Hanson KB, Van Loan MD, Genschel U, Koehler KJ (2007) Relationship of circulating total homocysteine and C-reactive protein to trabecular bone in postmenopausal women. J Clin Densitom 10:395-403. doi:10.1016/j.jocd.2007.06.002

16. Khandanpour N, Loke YK, Meyer FJ, Jennings B, Armon MP (2009) Homocysteine and peripheral arterial disease: systematic review and meta-analysis. Eur J Vasc Endovasc Surg 38:316-322. doi:10.1016/j. ejvs.2009.05.007

17. Wierzbicki AS (2007) Homocysteine and cardiovascular disease: a review of the evidence. Diab Vasc Dis Res 4:143-150. doi:10.3132/ dvdr.2007.033

18. Su D, Li Z, Li X, Chen Y, Zhang Y, Ding D, Deng X, Xia M, Qiu J, Ling W (2013) Association between serum interleukin-6 concentration and mortality in patients with coronary artery disease. Mediat Inflamm 2013:726178. doi:10.1155/2013/726178

19. Vicenová B, Vopálenský V, Burýsek L, Pospísek M (2009) Emerging role of interleukin-1 in cardiovascular diseases. Physiol Res 58:481-498

20. World Medical Association (2013) World Medical Association Declaration of Helsinki: ethical principles for medical research involving human subjects. JAMA 310:2191-2194. doi:10.1001/jama. 2013.281053

21. Miller M, Stone NJ, Ballantyne C, Bittner V, Criqui MH, Ginsberg HN, Goldberg AC, Howard WJ, Jacobson MS, Kris-Etherton PM, Lennie TA, Levi M, Mazzone T, American Heart Association Clinical Lipidology, Thrombosis, and Prevention Committee of the Council on Nutrition, Physical Activity, and Metabolism; Council on Arteriosclerosis, Thrombosis and Vascular Biology; Council on Cardiovascular Nursing; Council on the Kidney in Cardiovascular Disease (2011) Triglycerides and cardiovascular disease: a scientific statement from the American Heart Association. Circulation 123: 2292-2333. doi:10.1161/CIR.0b013e3182160726

22. Takahashi M, Masuyama J, Ikeda U, Kasahara T, Kitagawa S, Takahashi Y, Shimada K, Kano S (1995) Induction of monocyte chemoattractant protein-1 synthesis in human monocytes during transendothelial migration in vitro. Circ Res 76:750-757. doi:10. 1161/01.RES.76.5.750

23. Cushing SD, Berliner JA, Valente AJ, Territo MC, Navab M, Parhami F, Gerrity R, Schwartz CJ, Fogelman AM (1990) Minimally modified low density lipoprotein induces monocyte chemotactic protein 1 in human endothelial cells and smooth muscle cells. Proc Natl Acad Sci U S A 87:5134-5138

24. Sung FL, Slow YL, Wang G, Lynn EG, Karmin O (2001) Homocysteine stimulates the expression of monocyte chemoattractant protein-1 in endothelial cells leading to enhanced monocyte chemotaxis. Mol Cell Biochem 216:121-128. doi:10. 1023/A:1017383916068

25. Shyy YJ, Hsieh HJ, Usami S, Chien S (1994) Fluid shear stress induces a biphasic response of human monocyte chemotactic protein 1 gene expression in vascular endothelium. Proc Natl Acad Sci U S A 91:4678-4682

26. Ikeda U, Matsui K, Murakami Y, Shimada K (2002) Monocyte chemoattractant protein-1 and coronary artery disease. Clin Cardiol 25:143-147. doi:10.1002/clc.4960250403

27. Aiello RJ, Bourassa PA, Lindsey S, Weng W, Natoli E, Rollins BJ, Milos PM (1999) Monocyte chemoattractant protein-1 accelerates atherosclerosis in apolipoprotein E-deficient mice. Arterioscler Thromb Vasc Biol 19:1518-1525. doi:10.1161/01. ATV.19.6.1518

28. Reckless J, Rubin EM, Verstuyft JB, Metcalfe JC, Grainger DJ (1999) Monocyte chemoattractant protein-1 but not tumor necrosis factor-alpha is correlated with monocyte infiltration in mouse lipid lesions. Circulation 99:2310-2316. doi:10.1161/01.CIR.99.17.2310

29. Gosling J, Slaymaker S, Gu L, Tseng S, Zlot CH, Young SG, Rollins BJ, Charo IF (1999) MCP-1 deficiency reduces susceptibility to atherosclerosis in mice that overexpress human apolipoprotein B. J Clin Invest 103:773-778. doi:10.1172/JCI5624

30. Aukrust P, Müller F, Ueland T, Berget T, Aaser E, Brunsvig A, Solum NO, Forfang K, Frøland SS, Gullestad L (1999) Enhanced levels of soluble and membrane-bound CD40 ligand in patients with unstable angina. Possible reflection of T lymphocyte and platelet involvement in the pathogenesis of acute coronary syndromes. Circulation 100: 614-620. doi:10.1161/01.CIR.100.6.614

31. Hojo Y, Ikeda U, Takahashi M, Shimada K (2002) Increased levels of monocyte-related cytokines in patients with unstable angina. Atherosclerosis 161:403-408. doi:10.1016/S0021-9150(01)00636-0

32. Gonzalez-Quesada C, Frangogiannis NG (2009) Monocyte chemoattractant protein-1/CCL2 as a biomarker in acute coronary syndromes. Curr Atheroscler Rep 11:131-138. doi:10.1007/s11883009-0021-y

33. Libby $P$ (2002) Inflammation in atherosclerosis. Nature 420:868874. doi:10.1038/nature01323

34. Libby P, Ridker PM, Hansson GK (2011) Progress and challenges in translating the biology of atherosclerosis. Nature 473:317-325. doi: 10.1038/nature10146

35. von der Thüsen JH, Kuiper J, van Berkel TJ, Biessen EA (2003) Interleukins in atherosclerosis: molecular pathways and therapeutic potential. Pharmacol Rev 55:133-166. doi:10.1124/pr.55.1.5

36. Pudil R, Tichý M, Andrýs C, Rehácek V, Bláha V, Vojácek J, Palicka V (2010) Plasma interleukin-6 level is associated with NT-proBNP level and predicts short- and long-term mortality in patients with acute heart failure. Acta Med (Hradec Kralove) 53:225-228

37. Lee JK, Bettencourt R, Brenner D, Le TA, Barrett-Connor E, Loomba R (2012) Association between serum interleukin-6 concentrations and mortality in older adults: the Rancho Bernardo study. PLoS ONE 7:e34218. doi:10.1371/journal.pone.0034218

38. Wang M, Jin W, Guo AM, Stubbe J (2013) Cardiovascular inflammation. Mediat Inflamm 2013:123513. doi:10.1155/2013/123513 